\title{
ALTERATIONS OF THE ANTIOXIDANT ENZYME ACTIVITIES ARE NOT GENERAL CHARACTERISTICS OF THE COLONIZATION PROCESS BY ARBUSCULAR MYCORRHIZAL FUNGI
}

\author{
Yakelin Rodríguez $^{1 *}$, Horst Vierheilig ${ }^{2}$, and Luis M. Mazorra ${ }^{1,3}$
}

\begin{abstract}
Antioxidant system is involved in arbuscular mycorrhizal symbiosis, but its role during the colonization process is still poorly understood. To gain new insights into the role of antioxidant system during root colonization by arbuscular mycorrhizal fungi, the activities of key antioxidant enzymes were evaluated in tomato (Solanum lycopersicum L.) roots inoculated with six strains of different genera and species: two Glomus mosseae, Glomus cubense, Glomus intraradices, Glomus sp. and Acaulospora scrobiculata. Glomus cubense and A. scrobiculata strains reached the highest infectivity levels with maximum values of colonization frequency and intensity of 29-10.88\% and 18-9.20\%, respectively; G. mosseae strains showed an intermediate infectivity, both with $15 \%$ of colonization frequency and maximum intensities of 7.64$7.06 \%$, respectively; while the infectivity levels of Glomus sp. and G. intraradices strains were the lowest with colonization frequency- $13 \%$ and intensities- 5.07 and 5.41, respectively. Some activity patterns of peroxidase, superoxide dismutase, and polyphenol oxidase enzymes were not specific for early or late colonization stages neither for the colonization level and type of strain. However, a unique superoxide dismutase-band presents at early colonization and the low level of guaiacolperoxidase activity at later stages presents in all inoculated roots indicate that these antioxidant responses are independent of colonization degree and strain. Taking together, our data suggest that alterations of the antioxidant enzyme activities are not general characteristics of the colonization process by arbuscular mycorrhizal fungi, probably having the key role on those responses the specific feature of each strain rather than colonization per se.
\end{abstract}

Key words: Peroxidases, polyphenol oxidases, superoxide dismutase, colonization intensity, Solanum lycopersicum.

$\mathrm{T}$ he symbiotic association between arbuscular mycorrhizal fungi (AMF) and plants can be traced back to the Ordovician period and is widely distributed throughout the plant kingdom (Redecker et al., 2000). AMF colonizing plant roots are known for their beneficial effects on plant growth, pathogen protection, water and nutrient uptake, as well as improve soil aggregation (Smith and Read, 2008).

The establishment of this symbiosis involves a series of morpho-physiological and biochemical events, mediated by a complex exchange of signals, that are regulated by the interaction of the plant and the fungal genome, as well as by environmental factors (Vierheilig, 2004; Harrison, 2005; Hause and Fester, 2005; García-Garrido and Vierheilig, 2009). The molecular mechanisms controlling

\footnotetext{
${ }^{1}$ Instituto Nacional de Ciencias Agrícolas, Departamento Biofertilizantes y Nutrición de las Plantas, Carretera a Tapaste km 31/2, San José de las Lajas, gaveta postal 1, Mayabeque, Cuba. CP 32700. *Corresponding author (yakelin@inca.edu.cu).

${ }^{2}$ Consejo Superior de Investigaciones Científicas (CSIC), Estación Experimental de Zaidín, (18008) Granada, España.

${ }^{3}$ Universidad Nacional de la Plata, Instituto de Fisiología Vegetal, La Plata, Argentina.

Received: 7 November 2011

Accepted: 14 June 2012.
}

the colonization process and arbuscular mycorrhizal (AM) development are largely unknown, however, the induction/suppression of mechanisms associated with plant defense play a key role in AMF colonization and compatibility with its host (García-Garrido and Ocampo, 2002).

Reactive-oxygen-species are generated during the oxidative burst in plants resulting in an accumulation of $\mathrm{H}_{2} \mathrm{O}_{2}$ and are thought to play an important role in cell wall reinforcement, programmed death of elicited cells, and systemic induction of plant defense genes (Apel and Hirt, 2004). $\mathrm{A}_{2} \mathrm{O}_{2}$ accumulation has been detected around hyphal tips of AMF attempting penetration, in root cells containing intact and collapsed arbuscules, and even at the surface of intercellular fungal hyphae (Salzer et al., 1999; Fester and Hause, 2005), indicating that the control of AM intracellular growth is associated with a localized oxidative burst. Added, these authors suggested a connection of reactive-oxygen-species accumulation to mechanical damage, chemical stress, septum formation and to the degradation of arbuscules.

The induction of reactive-oxygen-species-scavenging enzymes, such as peroxidase (POX), superoxide dismutase (SOD) and polyphenol oxidase (PPO) is the most common mechanism for detoxifying reactive-oxygen-species 
synthesized during stress responses (Mittler, 2002; Matsumura et al., 2007; Kohler et al., 2009). POXs (EC 1.11.1.7) catalyze the oxidation of phenolic compounds using $\mathrm{H}_{2} \mathrm{O}_{2}$ as oxidant agent (Passardi et al., 2004), being guaiacol-peroxidase (GPX) among them. SOD (EC 1.15.1.1) catalyses the conversion of superoxide radicals to $\mathrm{H}_{2} \mathrm{O}_{2}$ and $\mathrm{O}_{2}$ (Fridovich, 1995). PPOs (EC 1.14.18.1 and EC 1.10.3.2) catalyze the oxide-reduction reactions of phenolic compounds with participation of $\mathrm{O}_{2}$ (Mayer, 2006).

Physiologically POXs and PPOs are involved in the oxidative polymerization of phenylpropanols to produce lignin, the formation of papillary structures and the crosslinking of cell wall proteins, contributing to plant cell wall reinforcement during pathogen penetration and stress situations, and might also be involved in scavenging $\mathrm{H}_{2} \mathrm{O}_{2}$ (Liszkay et al., 2004; Mayer, 2006).

Some authors (Pozo et al., 2002; Lambais et al., 2003; Pérez et al., 2004) have reported the induction/suppression of those enzymes and/or isoenzymes in plants during AM colonization indicating that they are somehow linked with the AM symbiotic process, however, their role in AMF symbiosis is still unknown.

Functional differences in interaction between AMF genera, species, even among strains within the same species have been found (Scervino et al., 2005; 2007; 2009). In which extend AMF-plant interactions determines specific or general changes on the antioxidant enzymes patterns remain controversial.

Here, we aimed at determining specific changes in peroxidase, superoxide dismutase, and polyphenol oxidase enzymes in tomato roots colonized by different AMF genera and species having different infectivity levels.

\section{MATERIALS AND METHODS}

\section{Plant material, inoculation and growth}

Tomato (Solanum lycopersicum L., cv. Amalia) seeds were surface-sterilized in a $10 \%$ sodium hypochlorite solution for $5 \mathrm{~min}$ and rinsed thoroughly with sterile distilled water. Thereafter seeds were sown in pots $(300$ $\mathrm{mL}$ ) containing a mixture of Typic Rhodudalf soil (Soil Survey Staff, 2006) and filter cake (a sugar cane byproduct enriched in nutrients) $(3 / 1, \mathrm{v} / \mathrm{v})$, sterilized by steaming $\left(121{ }^{\circ} \mathrm{C}\right.$ for $1 \mathrm{~h}$ during three following days). One plant per pot was grown and 20 pots per treatment were used.

Six AMF strains belonging to Glomus and Acaulospora genera were isolated from different Cuban localities and subcultivated separately in multiplication pots containing Sorghum bicolor as a trap plant. These strains are morphologically different (Table 1) and belong to AMF collection of Instituto Nacional de Ciencias Agrícolas, Cuba. The strains were: Glomus cubense (Y. Rodr. \& Dalpé) (Rodríguez et al., 2011), two Glomus

Table 1. Principal morphological characteristics and origin of the studied arbuscular mycorrhizal fungi strains.

\begin{tabular}{|c|c|c|c|c|c|c|c|}
\hline $\begin{array}{l}\text { Species } \\
\text { (code) }\end{array}$ & Abbrev. & Isolated from & Color & Shape & Size $(\mu \mathrm{m})$ & $\begin{array}{l}\text { Layer number } \\
\text { of spore wall }\end{array}$ & Picture \\
\hline $\begin{array}{l}\text { Glomus cubense } \\
\text { (INCAM-4) }\end{array}$ & $\mathrm{Gcb}$ & $\begin{array}{l}\text { San José } \\
\text { de las Lajas }\end{array}$ & $\begin{array}{l}\text { Hyaline to very } \\
\text { light yellow }\end{array}$ & $\begin{array}{l}\text { Ovoid, ellipsoid, } \\
\text { pyriform to irregular }\end{array}$ & $20-80$ & 2 & \\
\hline $\begin{array}{l}\text { Glomus mosseae } 1 \\
\text { (INCAM-2) }\end{array}$ & $\mathrm{Gm} 1$ & Güira & Yellow-amber & Globose, subglobose & $100-260$ & 3 & \\
\hline $\begin{array}{l}\text { Glomus mosseae } 2 \\
\text { (INCAM-5) }\end{array}$ & $\mathrm{Gm} 2$ & $\begin{array}{l}\text { Rizosphere of } \\
\text { Palma tree, } \\
\text { Mayabeque }\end{array}$ & Pale orange & Globose, subglobose & $100-260$ & 3 & \\
\hline $\begin{array}{l}\text { Glomus sp. } \\
\text { (INCAM-1) }\end{array}$ & Gsp & Güira & Yellow & Globose & $60-110$ & 3 & \\
\hline $\begin{array}{l}\text { Glomus intraradices } \\
\text { (INCAM-9) }\end{array}$ & $\mathrm{Gi}$ & Tope de Collantes & Reddish brown & $\begin{array}{l}\text { Globose, subglobose, } \\
\text { irregular }\end{array}$ & $70-130$ & 3 & \\
\hline $\begin{array}{l}\text { Acaulospora } \\
\text { scrobiculata } \\
\text { (INCAM-10) }\end{array}$ & Asc & Tope de Collantes & Hyaline & Globose & $100-160$ & 3 & \\
\hline
\end{tabular}


mosseae strains (Nicol. \& Gerd. emend. Gerd. \& Trappe), Glomus intraradices (Schenck \& Smith), Glomus sp. and Acaulospora scrobiculata (Trappe). These six AMF strains inoculated separately in tomato plants and control plants without inoculation were the seven treatments studied.

The inoculation was performed using a 200 spore suspension ( $100 \%$ of viability and $95-97 \%$ of germination) of each AMF strain per pot at sowing time. Spores were isolated employing the technique described by Gerdemann and Nicholson (1963). Previously these spores were surface sterilized with Chloramine $\mathrm{T}$ solutions (2\% and $5 \%$ ) and successive washings with sterile water.

Tomato plants were grown in a greenhouse $(23 \pm 2$ ${ }^{\circ} \mathrm{C}$ temperature, $80-85 \%$ relative humidity and natural illumination). Plants were harvested 18 and $32 \mathrm{~d}$ after germination based on a previous study (Pérez et al., 2004). Height, root and shoot fresh and dry weights were determined. The total fresh and dry weights were calculated.

Root systems were carefully washed with tap water, rinsed with distilled water and weighed. Approximately $200 \mathrm{mg}$ of secondary root of each system were stained according to Phillips and Hayman (1970) and the AM colonization frequency (\%) and intensity (\%) were determined (Trouvelot et al., 1986).

\section{Protein extraction and quantification}

Fresh roots were ground at $4{ }^{\circ} \mathrm{C}$ in an ice-chilled mortar with liquid nitrogen and the resulting powder was suspended in $50 \mathrm{mM}$ Tris- $\mathrm{HCl}$ buffer $(\mathrm{pH} 7.2)(1 / 1, \mathrm{w} / \mathrm{v})$, with $10 \%$ sucrose, $0.1 \% \quad \beta$-mercaptoethanol and $5 \%$ polyvinylpirrolidone. Crude homogenates were agitated in a shaker for $45 \mathrm{~min}$ in an ice bath and centrifuged at $14000 \mathrm{rpm}$ for $25 \mathrm{~min}$ at $4{ }^{\circ} \mathrm{C}$. The supernatant was kept frozen at $-20{ }^{\circ} \mathrm{C}$. The protein content was determined by the Bradford method using bovine serum albumin as standard (Bradford, 1976).

\section{Enzymatic assays}

The GPX and PPO activities were determined in tomato root extracts using spectrophotometer (Ultrospec Plus Spectrophotometer, Pharmacia LKB, Piscataway, New Jersey, USA). The GPX activity was measured monitoring guaiacol oxidation at $470 \mathrm{~nm}$ according to method described by Frick (1976). The PPO activity was determined monitoring pirogallol oxidation during one min with intervals of $5 \mathrm{~s}$ at $420 \mathrm{~nm}$ by the method described by Alexander (1964). Specific enzymatic activities were expressed as Units $\mathrm{mg}^{-1}$ protein.

\section{Isoenzymatic detection}

Isoenzyme patterns were determined in root extracts and analyzed by native polyacrylamide gel electrophoresis (Davis, 1964) with the following modification: stacking gel- $4 \%$ polyacrylamide and separating gel- $8.5 \%$ and
$10 \%$ for POX and SOD, respectively. Electrophoreses were run with $19 \mathrm{mM}$ Tris-Glycine buffer ( $\mathrm{pH} 8.3$ ) at 25 $\mathrm{mA}$ for $2 \mathrm{~h}$ at $4{ }^{\circ} \mathrm{C}$ in a BIORAD vertical system. Each lane was loaded with $20 \mu \mathrm{g}$ protein.

The POX isoenzymes on gel were revealed by staining with acetic acid-benzydin solution and hydrogen peroxide solution (1/1, v/v) (Vallejos, 1983). SOD isoenzymes on gel were detected by the photochemical nitroblue tetrazolium (Sigma reagent) staining method according to Beauchamp and Fridovich (1971). Gels were photographed using Nikon F90X camera, lens zoom 2885 (Konica film) and scanned (Acer Slim6) and the relative mobility (RM) value for each isoenzyme was assessed.

\section{Statistical analysis}

Three independent experiments were carried out, each with 20 replicate plants per treatment, in a completely randomized design. Mean values of three independent experiments were subjected to ANOVA, followed by Duncan test with $\mathrm{p}<0.05$ using a SPSS 11.5 software (SPSS Inc., Chicago, Illinois, USA) when appropriate. Electrophoreses analyses were repeated at least three times.

\section{RESULTS AND DISCUSSION}

\section{Root colonization by AMF}

Our results evidenced that all AMF strains colonized tomato roots; however, the colonization development varied. The colonization frequency and intensity differed significantly depending on the AMF strain at both sampling times (Table 2). These two variables were highest in plants inoculated with G. cubense (Gcb) at 32 $\mathrm{d}$ after inoculation, indicating that under our experimental conditions this strain is the most infective, followed by A. scrobiculata (Asc). All other AMF strains showed a lower colonization frequency without significant differences between each other, but, their colonization intensities varied statistically. Glomus intraradices (Gi) and Glomus sp. (Gsp) treatments showed the lowest levels of colonization intensity at day 32, representing the least infective strains in this study. Whereas, plants inoculated

Table 2. Colonization frequency and intensity of tomato roots noninoculated and inoculated with six arbuscular mycorrhizal fungal strains, at 18 and $32 \mathrm{~d}$ after germination.

\begin{tabular}{|c|c|c|c|c|}
\hline \multirow[b]{2}{*}{ Treatments } & \multicolumn{2}{|c|}{ Colonization frequency } & \multicolumn{2}{|c|}{ Colonization intensity } \\
\hline & $18 \mathrm{~d}$ & $32 \mathrm{~d}$ & $18 \mathrm{~d}$ & $32 \mathrm{~d}$ \\
\hline & & & $\%$ & \\
\hline Control plants & Od & Od & $0 \mathrm{e}$ & Od \\
\hline Glomus cubense & $14 \pm 0.02 \mathrm{a}$ & $29 \pm 0.05 a$ & $645 \pm 0.02 \mathrm{a}$ & $10.88 \pm 0.03 a$ \\
\hline G. mosseae 1 & $10 \pm 0.02 b c$ & $15 \pm 0.04 b c$ & $499 \pm 0.03 b c$ & $7.64 \pm 0.01 \mathrm{c}$ \\
\hline G. mosseae 2 & $9 \pm 0.01 b c$ & $15 \pm 0.03 b c$ & $400 \pm 0.01 c$ & $7.06 \pm 0.02 \mathrm{c}$ \\
\hline Glomus sp. & $8 \pm 0.01 \mathrm{c}$ & $13 \pm 0.02 c$ & $217 \pm 0.02 \mathrm{~d}$ & $5.07 \pm 0.02 \mathrm{~d}$ \\
\hline G. intraradices & $7 \pm 0.01 \mathrm{c}$ & $13 \pm 0.03 c$ & $223 \pm 0.01 \mathrm{~d}$ & $5.41 \pm 0.01 d$ \\
\hline $\begin{array}{l}\text { Acaulospora } \\
\text { scrobiculata }\end{array}$ & $12 \pm 0.02 \mathrm{ab}$ & $18 \pm 0.04 b$ & $589 \pm 0.04 a b$ & $9.20 \pm 0.06 b$ \\
\hline
\end{tabular}

Data in each column (mean of three independent experiments \pm SE) followed by common letters do not differ significantly according to Duncan test $(\mathrm{p}<0.05)$ 
with the two G. mosseae strains (Gm1 and Gm2) showed lower values of this variable than treatment with $A$. scrobiculata (Asc) after $32 \mathrm{~d}$, suggesting an intermediate infectivity. No signs of AM root colonization were observed in the control plants.

Although numerous works emphasize on structural and mainly, functional differences between AMF genera, species and even strains, less data are available on differences of the infectivity level. Lambais et al. (2003) reported that when beans were inoculated with two Glomus species, G. clarum was more infective than $G$. intraradices; and with two $G$. intraradices in soybean roots even on strain level differences of the infectivity level was observed (Lambais and Mehdy, 1996). This result contrasts with our study, where the equal infectivity at strain level was observed, but we used G. mosseae. For other hand, Pozo et al. (2002) found similar percentages of root length colonized in tomato inoculated with $G$. mosseae and $G$. intraradices. Nevertheless, recent work testing those same species demonstrated differences in their infectivity on tomato plants (López-Ráez et al., 2010).

It could be due to these authors determined only the colonization frequency to estimate the infectivity of analyzed strains, without taking in account the intensity. However, our results revealed that this variable (intensity) is more useful to establish the infectivity differences at deeper level when many strains are examined. In this sense, Jansa et al. (2009) found that infectivity can serve as an indicator of soil quality.

\section{Plant growth}

At $18 \mathrm{~d}$, differences between mycorrhized and nonmycorrhized treatments were found in the most analyzed growth variables (Table 3), showing mycorrhized plants superior values. Nevertheless, at 32 d, differences not only between non-inoculated and inoculated treatments were detected, but also among inoculated plants with distinct AMF strains. Plants colonized with G. cubense (Gcb), $G$. intraradices (Gi), and both G. mosseae ( $\mathrm{Gm} 1$ and $\mathrm{Gm} 2$ ) presented higher height and total fresh weight in the second sampling time. Similar results were observed in total dry weight excluding the G. mosseae 2 treatment (Gm2). Since total dry weight is the most important growth variable evaluated, we consider $G$. cubense, $G$. mosseae 1 and $G$. intraradices strains like more efficient under studied conditions. The differences found in plant growth among colonized treatments were probably caused by mycorrhization effect with each strain. Similar results demonstrating the benefit of AMF to plant growth have been observed by many authors (Rivera et al., 2007; Smith and Read, 2008).

\section{GPX and PPO activities}

The changes of the GPX activity seemed to depend on the AMF strain and the stage of colonization. At day 18 (Figure 1) both $G$. mosseae treatments ( $\mathrm{Gm} 1$ and $\mathrm{Gm} 2$ ) reached higher values of GPX activity, occurring highest induction in G. mosseae2 (Gm2) treatment. GPX activity of roots colonized by G. cubense and Glomus sp. (Gcb and Gsp) showed a clearly reduction; however, the colonization with $G$. intraradices (Gi) and A. scrobiculata (Asc) did not affect GPX activity. At day 32 a drastic decrease of this enzymatic activity was observed in all treatments. The decrease was more drastic in the mycorrhizal treatments than in the non-mycorrhizal control plant, with highest activity in the Glomus sp. (Gsp) plants.

Studies with Allium porrum L. colonized by $G$. mosseae (Spanu and Bonfante-Fasolo, 1988) and Zea mays L. colonized by G. intraradices (Fries et al., 1996)

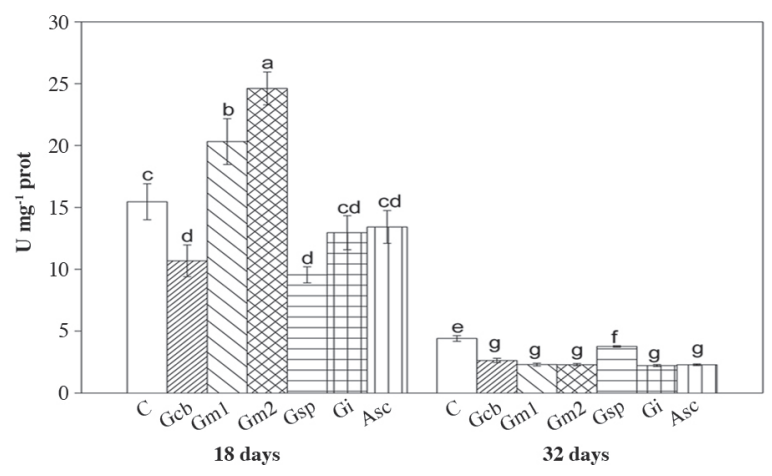

Bars with common letters do not differ significantly according to Duncan test $(\mathrm{p}<0.05)$. C: control; Gcb: Glomus cubense; Gm1: G. mosseae1; Gm2: G. mosseae2; Gsp: Glomu sp.; Gi: G. intraradices; Asc: Acaulospora scrobiculata.

Figure 1. Guaiacol-peroxidase specific activity of tomato roots noninoculated and inoculated with six arbuscular mycorrhizal fungal strains, at 18 and $32 \mathrm{~d}$ after germination.

Table 3. Height and total fresh and dry weights of tomato plants non-inoculated and inoculated with six arbuscular mycorrhizal fungal strains, at 18 and $32 \mathrm{~d}$ after germination.

\begin{tabular}{|c|c|c|c|c|c|c|}
\hline \multirow[b]{2}{*}{ Treatments } & \multicolumn{2}{|c|}{ Height } & \multicolumn{2}{|c|}{ Total fresh weight } & \multicolumn{2}{|c|}{ Total dry weight } \\
\hline & $18 \mathrm{~d}$ & $32 \mathrm{~d}$ & $18 \mathrm{~d}$ & $32 \mathrm{~d}$ & $18 \mathrm{~d}$ & $32 \mathrm{~d}$ \\
\hline & 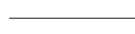 & - & & 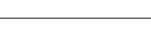 & 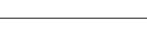 & 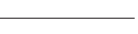 \\
\hline Control & $6.36 \pm 0.40 b$ & $15.15 \pm 0.77 \mathrm{c}$ & $0.42 \pm 0.05 \mathrm{c}$ & $6.69 \pm 0.29 b$ & $0.05 \pm 0.01 \mathrm{c}$ & $0.68 \pm 0.12 \mathrm{~d}$ \\
\hline Glomus cubense & $8.96 \pm 0.36 \mathrm{a}$ & $18.50 \pm 1.06 \mathrm{ab}$ & $2.29 \pm 0.09 \mathrm{a}$ & $13.75 \pm 0.28 \mathrm{a}$ & $0.22 \pm 0.01 \mathrm{ab}$ & $1.47 \pm 0.18 \mathrm{a}$ \\
\hline G.mosseae 1 & $8.00 \pm 0.71 \mathrm{a}$ & $18.50 \pm 1.04 \mathrm{ab}$ & $1.94 \pm 0.13 \mathrm{a}$ & $12.22 \pm 0.83 \mathrm{a}$ & $0.25 \pm 0.03 \mathrm{ab}$ & $1.54 \pm 0.12 \mathrm{a}$ \\
\hline G.mosseae 2 & $8.02 \pm 0.37 \mathrm{a}$ & $20.00 \pm 0.71 \mathrm{a}$ & $2.14 \pm 0.15 \mathrm{a}$ & $13.64 \pm 1.38 \mathrm{a}$ & $0.25 \pm 0.06 \mathrm{ab}$ & $1.07 \pm 0.20 b c$ \\
\hline Glomus sp. & $8.82 \pm 0.59 \mathrm{a}$ & $16.30 \pm 0.87 \mathrm{bc}$ & $1.31 \pm 0.07 b$ & $8.33 \pm 0.90 b$ & $0.14 \pm 0.03 b$ & $0.95 \pm 0.14 c$ \\
\hline G. intraradices & $8.50 \pm 0.54 a$ & $20.12 \pm 0.77 \mathrm{a}$ & $2.22 \pm 0.11 \mathrm{a}$ & $13.36 \pm 0.83 \mathrm{a}$ & $0.38 \pm 0.16 \mathrm{a}$ & $1.30 \pm 0.10 \mathrm{ab}$ \\
\hline Acaulospora scrobiculata & $8.12 \pm 0.59 \mathrm{a}$ & $17.05 \pm 1.05 \mathrm{bc}$ & $1.97 \pm 0.15 \mathrm{a}$ & $7.02 \pm 0.52 b$ & $0.20 \pm 0.02 \mathrm{ab}$ & $0.79 \pm 0.09 \mathrm{~d}$ \\
\hline
\end{tabular}

Data in each column (mean of three independent experiments \pm SE) followed by common letters do not differ significantly according to Duncan test $(\mathrm{p}<0.05$ ). 
showed transient and weak increments of POX activity at early colonization stages and decreases during the full establishment of the AM symbiosis. This behavior coincides with those observed for two G. mosseae strains in the present study, which relates with an intermediate infectivity. It suggests that the trigger of the GPX activity influences leading to an initial restriction of G. mosseae penetration. Increased GPX activity could play a role in the wall reinforcement (Liszkay et al., 2004), likely limiting colonization.

Changes of the PPO activity also depended on the AMF strain and the stage of colonization. G. mosseae 1 treatment $(\mathrm{Gm} 1)$ reached slight higher values at day 18 (Figure 2); however, PPO activity of roots colonized by Glomus sp. (Gsp), G. intraradices (Gi) and A. scrobiculata (Asc) was significantly lower. Polyphenol oxidase activity also decreased drastically while advancing colonization (32 d). The G. intraradices (Gi) and A. scrobiculata (Asc) treatments showed a similar activity as the nonmycorrhizal control, whereas all other mycorrhizal treatments still showed increased PPO activities.

Increased PPO activity and a new PPO-isoform were detected in three species of Ziziphus inoculated with Glomus fasciculatum (Mathur and Vyas, 1995). Nevertheless, Pérez et al. (2004) found increments in PPO activity at early colonization stages for tomato interaction with $G$. clarum and $G$. claroideum, but not with $G$. fasciculatum neither $A$. scrobiculata; whereas at late colonization stages only G. clarum and A. scrobiculata increased this activity. Our results agree with those variations.

This enzyme also plays a role in the cell wall reinforcement and in reactive-oxygen-species scavenging (Mayer, 2006), similar to GPX. However, PPO activity showed a differing activity in plants inoculated with $G$. mosseae 1 or G. mosseae 2 , at early colonization stage. In this context is important to highlight the involvement of GPX in cell wall loosening in plants (Liszkay et al.,

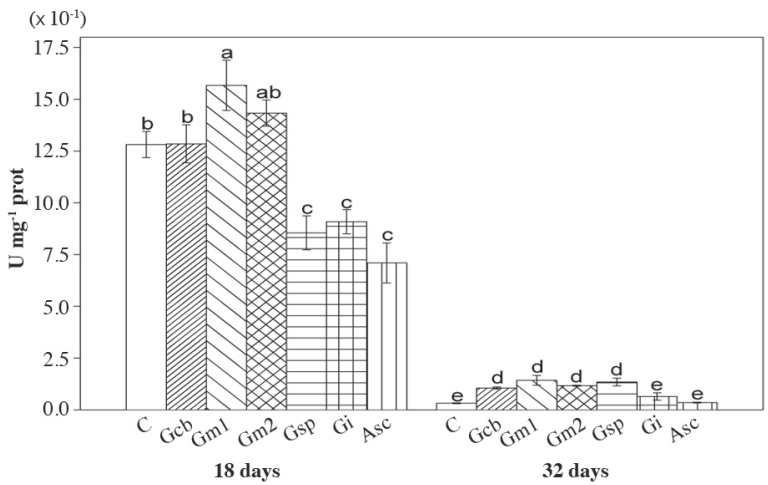

Bars with common letters do not differ significantly according to Duncan test $(\mathrm{p}<0.05)$. C: control; Gcb: Glomus cubense; Gm1: G. mosseae1; Gm2: G. mosseae2; Gsp: Glomus sp.; Gi: G. intraradices; Asc: Acaulospora scrobiculata.

Figure 2. Polyphenol oxidase specific activity of tomato roots noninoculated and inoculated with six arbuscular mycorrhizal fungal strains, at 18 and $32 \mathrm{~d}$ after germination.
2003; 2004), likely, during AMF penetration similar mechanisms mediated by reactive-oxygen-species and reactive-oxygen-species-scavenging enzymes occur. It may arise parallel to activity increments of enzymes degrading plant cell wall, as has been demonstrated by Morales Vela et al. (2007) and García et al. (2008).

As may be expected, enzymatic activities of $G$. cubense, A. scrobiculata and both G. mosseae strains do not look like similar each other, indicating that differences in infectivity between them have influence on antioxidant response. Specific fluctuations in GPX and PPO activities may be a peculiar response within strains, but changes in particular isoenzymes can be likely more informative having higher capacity for strain discrimination.

\section{POX isoenzyme patterns}

After $18 \mathrm{~d}$, four POX-bands were detected in root extracts (Figure 3), corresponding to constitutive isoforms. But in $G$. intraradices treatment only the band with lower migration $\left(\mathrm{N}^{\circ} 4\right)$ was visible, this strain seemed to repress the activity of some constitutive isoforms.

Three POX-bands were seen at $32 \mathrm{~d}$ (Figure 4). Control roots showed only a very faint band with higher mobility $\left(\mathrm{N}^{\circ} 1\right)$. In roots colonized by A. scrobiculata (Asc) all three isoforms were visible, while in the treatments with G. mosseae1 (Gm1), G. mosseae2 (Gm2) and G. cubense $(\mathrm{Gcb})$ the band with lower migration was absent $\left(\mathrm{N}^{\circ} 3\right)$. In the Glomus sp. (Gsp) and G. intraradices (Gi) only the band $\mathrm{N}^{\circ} 1$ was seen. The POX-bands with lower and higher migration were the most intensive in $A$. scrobiculata (Asc) and G. mosseae1, respectively.

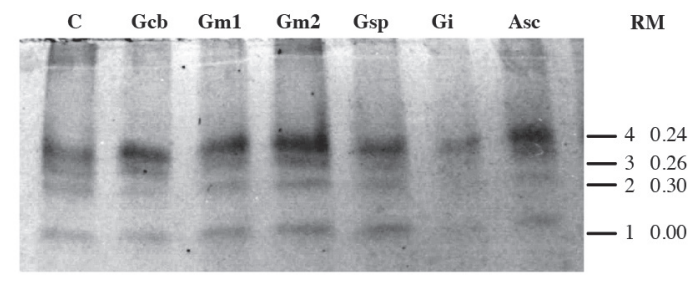

C: control; Gcb: Glomus cubense; Gm1: G. mosseae1; Gm2: G. mosseae2; Gsp: Glomus sp.; Gi: G. intraradices; Asc: Acaulospora scrobiculata.

Figure 3. Peroxidase isoenzyme pattern of tomato roots non-inoculated and inoculated with six arbuscular mycorrhizal fungal strains, at $18 \mathrm{~d}$ after germination, and isoenzyme relative mobility (RM).

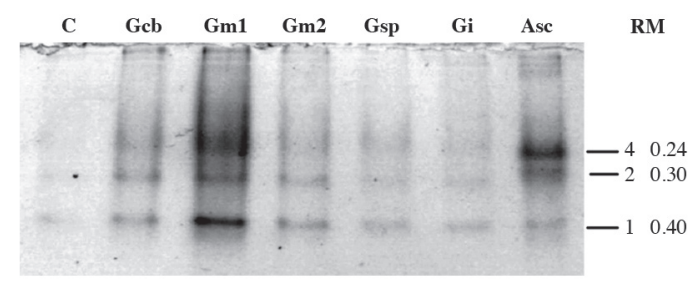

C: control; Gcb: Glomus cubense; Gm1: G. mosseae1; Gm2: G. mosseae2; Gsp: Glomus sp.; Gi: G. intraradices; Asc: Acaulospora scrobiculata.

Figure 4. Peroxidase isoenzyme pattern of tomato roots non-inoculated and inoculated with six arbuscular mycorrhizal fungal strains, at $32 \mathrm{~d}$ after germination, and isoenzyme relative mobility (RM). 
New POX-isoforms were detected in Ziziphus and tomato roots colonized with G. fasciculatum and G.clarum, respectively, but not in tomato-G. fasciculatum interaction (Mathur and Vyas, 1995; Rodríguez et al., 2001). In contrast, Fries et al. (1996) and Pozo (1999) found only quantitative differences of root POX-isoenzyme patterns in the interactions corn- $G$. intraradices and tomato- $G$. mosseae. Our results correspond with those of Fries et al. (1996) and Pozo (1999); no new isoforms were induced by any of the AMF at evaluated periods.

\section{SOD isoenzyme patterns}

One constitutive SOD-band (RM 0.59) was clearly found at both sampling dates (Figures 5 and 6). This band was present in all treatments at day 18 , but disappeared in roots inoculated with G. cubense (Gcb), A. scrobiculata (Asc) and both G. mosseae strains ( $\mathrm{Gm} 1$ and $\mathrm{Gm} 2)$, at day 32 . Additional isoforms were not detected in any treatment at analyzed times.

Two new SOD-isoforms in G. mosseae-inoculated red clover (Palma et al., 1993) and a specific Mn-SOD isoform in tomato roots mycorrhized with $G$. mosseae and G. intraradices were induced (Pozo et al., 2002). Contradictory, SOD-isoenzyme pattern of pea root inoculated with $G$. mosseae was not altered (Arines et al., 1994). Martin et al. (1998) observed induction of a new SOD-isoform in onion and clover inoculated with $G$. mosseae, but not with $G$. intraradices. The results of present work accord with Arines et al. (1994) and with Martin et al. (1998) just for G. intraradices.

POX and SOD isoenzyme patterns at early colonization stage were not specific for G. mosseae strains. Similarly,

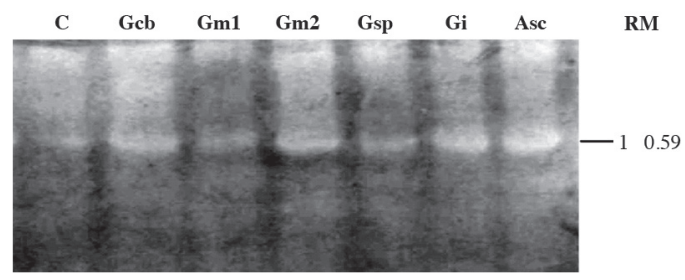

C: control; Gcb: Glomus cubense; Gm1: G. mosseae1; Gm2: G. mosseae2; Gsp: Glomus sp.; Gi: G. intraradices; Asc: Acaulospora scrobiculata.

Figure 5. Superoxide dismutase isoenzyme pattern of tomato roots noninoculated and inoculated with six arbuscular mycorrhizal fungal strains, at $18 \mathrm{~d}$ after germination, and the isoenzyme relative mobility (RM).

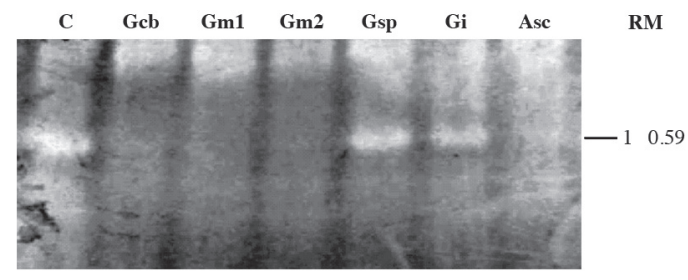

C: control; Gcb: Glomus cubense; Gm1: G. mosseae 1; Gm2: G. mosseae2; Gsp: Glomus sp.; Gi: G. intraradices; Asc: Acaulospora scrobiculata.

Figure 6. Superoxide dismutase isoenzyme pattern of tomato roots noninoculated and inoculated with six arbuscular mycorrhizal fungal strains, at $32 \mathrm{~d}$ after germination, and isoenzyme relative mobility (RM). the higher colonization of G. cubense and A. scrobiculata strains did not relate to appreciable changes on GPX and PPO activities neither altered POX and SOD patterns, at early stage; suggesting that these enzymes in this period are not directly relate to infectivity or efficiency of AMF. Similar responses of these enzymes between tested strains during early colonization suggest that common oxidative mechanisms (i.e., increased antioxidant capacity and decreased reactive-oxygen-species over-production) may act regulating fungal penetration. However, at late stage, significant alterations in both isoenzyme patterns were observed, which were according to infectivity levels of strains.

The colonization intensity of Glomus sp. and $G$. intraradices strains links with an early inhibition of PPO activity, likely retarding AMF penetration, as well as with SOD and POX patterns at day 32. The behavior of GPX activity, PPO at late stage of colonization and POXisoenzymes at day 18 , were different suggesting that those strains develop different mechanisms to colonize tomato roots. The data suggest that AMF colonization does not exert a specific enzyme, but it is a combination of all of them that determine the infectivity and efficiency of each strain.

Here, antioxidant activity patterns studied were unspecific and showed variations with the colonization level of AMF strains. This fact is consistent with previous works showing that a differential induction and/or activities of antioxidant enzymes vary with the different infectivity levels of AMF species and strains (Lambais and Mehdy, 1996; Lambais et al., 2003). The lack of specificity in changes of antioxidant enzymes indicates that these could not be good markers for strain specificity during distinct stages of colonization. Further experiments should be done to help discriminate between the influence of strain features and the level of colonization on antioxidant responses.

The unique SOD-band present at early colonization and the low level of GPX activity at later stages coincided in all AMF inoculations with independence of colonization degree and strain. These activities seem to be general responses of mycorrhization under the studied conditions, not discriminating differences in rate of infectivity among strains. This suggests that these specific antioxidant responses are independent of AMF colonization.

\section{CONCLUSIONS}

In summary, our data indicate that isoenzymatic and enzymatic alterations of antioxidant systems are not general characteristics of the colonization process by arbuscular mycorrhizal fungi and are independent of infectivity level and AMF strain.

Based on available data, we can speculate that the specific feature of each strain rather than colonization per $s e$ plays the key role in plant response related to antioxidant 
enzymes leading to differential colonization strategies according on AMF strain involved. Although, the test of a larger AMF species as well as deepen on determining a major number of enzyme activities, isoenzyme patterns and other compounds like reactive-oxygen-species is needed to prove that.

\section{ACKNOWLEDGEMENTS}

This research was supported by the "International Foundation for Science" (grant $\mathrm{N}^{\circ} \mathrm{C}-4463$ ) given to YR. The authors thank Aida Medina for her technical assistance.

\section{Alteraciones de las actividades de enzimas antioxidantes no son características generales del proceso de colonización por hongos micorrízicos arbusculares. El sistema antioxidante está involucrado en la simbiosis micorrízico-arbuscular, pero su rol} durante el proceso de colonización es aún escasamente comprendido. Para esclarecer el papel del sistema antioxidante durante la colonización radical por los hongos micorrízicos arbusculares, se evaluaron las actividades de enzimas antioxidantes claves en raíces de tomate (Solanum lycopersicum L.) inoculadas con seis cepas diferentes: dos Glomus mosseae, Glomus cubense, Glomus intraradices, Glomus sp. y A. scrobiculata. Las cepas $G$. cubense y A. scrobiculata alcanzaron los niveles de infectividad superiores con valores máximos de colonización e intensidad de $29-10,88 \%$ y $18-9,20 \%$, respectivamente; las cepas G. mosseae mostraron una infectividad intermedia, ambas con 15\% de colonización e intensidades máximas de 7,64-7,06\%, respectivamente; mientras que los niveles de infectividad de las cepas Glomus sp. y $G$. intraradices fueron inferiores con colonización del $13 \%$ e intensidades de 5,07 y 5,41, respectivamente. Algunos patrones de actividad de las enzimas peroxidasa, superóxido dismutasa y polifenol oxidasa no resultaron específicos para los niveles y estadios de colonización, temprano o tardío, ni tipo de cepa. No obstante, la única banda de superóxido dismutasa presente en la colonización temprana y el bajo nivel de actividad guayacol-peroxidasa en estadio tardío presente en todos los tratamientos micorrizados indican que estas respuestas antioxidantes son independientes de la cepa y el grado de colonización. En conjunto, los datos sugieren que las alteraciones de las actividades enzimáticas antioxidantes no son características generales del proceso de colonización por los hongos micorrízicos arbusculares, teniendo probablemente el rol clave sobre estas respuestas las características específicas de cada cepa más que la colonización per se.

Palabras clave: peroxidasas, polifenol oxidasas, superóxido dismutasa, intensidad de la colonización, Solanum lycopersicum.

\section{LITERATURE CITED}

Alexander, A.G. 1964. Sucrose enzyme relationship in immature sugar cane. Journal of Agriculture of the University of Puerto Rico 4813:165-231.

Apel, K., and H. Hirt. 2004. Reactive oxygen species: metabolism, oxidative stress, and signal transduction. Annual Review of Plant Biology 55:373-399.

Arines, J., M. Quintela, A. Vilarino, and J.M. Palma. 1994. Protein patterns and superoxide dismutase activity in non-mycorrhizal and arbuscular mycorrhizal Pisum sativum L. plants. Plant and Soil 166:37-45.

Beauchamp, C.O., and I. Fridovich. 1971. Superoxide dismutase: improved assays and an assay applicable to acrylamide gels. Analytical Biochemistry 44:276-287.

Bradford, M.M. 1976. A rapid and sensitive method for the quantification of microgram quantities of protein utilizing the principle of protein dye binding. Analytical Biochemistry 73:248-250.

Davis, B.J. 1964. Disc electrophoresis. II. Method and application to human serum proteins. Annuals of the New York Academy of Science 121:404-427.

Fester, T., and G. Hause. 2005. Accumulation of reactive oxygen species in arbuscular mycorrhizal roots. Mycorrhiza 15:373-379.

Frick, F. 1976. Oxidative enzymes. p. 617-627. In Heitefuss, R., and P.H. Williams (eds.) Physiological plant pathology. Encyclopedia of Plant Pathology, New Series 4. Springer-Verlag, New York, USA.

Fridovich, I. 1995. Superoxide radical and superoxide dismutases. Annual Review of Biochemistry 64:97-112.

Fries, LL.M., R.S. Pacovsky, and G.R. Safir. 1996. Expression of isoenzymes altered by both Glomus intraradices colonization and formononetin application in corn (Zea mays L.) roots. Soil Biology and Biochemistry 28:981-988.

García, M., G. Morales-Vela, J.M. García-Garrido, I. GarcíaRomera, y J.A. Ocampo. 2008. Enzimas que intervienen en la formación y desarrollo de la simbiosis arbuscular. p. 230-248. In A.G. Heredia (ed.) Tópicos sobre diversidad, ecología y usos de los hongos microscópicos en Iberoamérica. Instituto de Ecología, A.C., Xalapa, Veracruz, México.

García-Garrido, J.M., and J.A. Ocampo. 2002. Regulation of the plant defence response in arbuscular mycorrhizal symbiosis. Journal of Experimental Botany 53:1377-1386

García-Garrido, J.M., and H. Vierheilig. 2009. From a germinating spore to an established arbuscular mycorrhiza: Signalling and regulation. p. 15-37. In D. Khasa et al. (eds.) Advances in mycorrhizal science and technology. NRC Research Press, Ottawa, Canada.

Gerdemann, J.W., and T.H. Nicholson. 1963. Spore of mycorrhizae endogone species extracted from soil by wet sieving and decanting. Transactions of British Mycological Society 46:235-244.

Harrison, M.J. 2005. Signaling in the arbuscular mycorrhizal symbiosis. Annual Review of Microbiology 59:19-42.

Hause, B., and T. Fester. 2005. Molecular and cell biology of arbuscular mycorrhizal symbiosis. Planta 221:184-196.

Jansa, J.,H-R. Oberholzer, and S.Egli. 2009. Environmental determinants of the arbuscular mycorrhizal fungal infectivity of Swiss agricultural soils. European Journal of Soil Biology 45:400-408.

Kohler, J., J.A. Hernández, F. Caravaca, and A. Roldán. 2009. Induction of antioxidant enzymes is involved in the greater effectiveness of a PGPR versus AM fungi with respect to increasing the tolerance of lettuce to severe salt stress. Environmental and Experimental Botany 65:245-252.

Lambais, M.R., and M.C. Mehdy. 1996. Soybean roots infected by Glomus intraradices strains differing in infectivity exhibit differential chitinase and $\beta$-1,3-glucanase expression. New Phytologist 134:531-538.

Lambais, M.R., W.F. Ríos-Ruiz, and R.M. Andrade. 2003. Antioxidant responses in bean (Phaseolus vulgaris) roots colonized by arbuscular mycorrhizal fungi. New Phytologist 160:421-428. 
Liszkay, A., B. Kenk, and P. Schopfer. 2003. Evidence for the involvement of cell wall peroxidase in the generation of hydroxyl radicals mediating extension growth. Planta 217:658-667.

Liszkay, A., E. Van der Zalm, and P. Schopfer. 2004. Production of reactive oxygen intermediates $\left(\mathrm{H}_{2} \mathrm{O}_{2}\right.$, and $\left.\mathrm{OH}\right)$ by maize roots and their role in wall loosening and elongation growth. Plant Physiology 136:3114-3123.

López-Ráez, J.A., A. Verhage, I. Fernández, J.M. García, C. Azcón-Aguilar, V. Flors, and M.J. Pozo. 2010. Hormonal and transcriptional profiles highlight common and differential host responses to arbuscular mycorrhizal fungi and the regulation of the oxylipin pathway. Journal of Experimental Botany 61:25892601.

Martin, J., I. García-Romero, J.A. Ocampo, and J.M. Palma. 1998. Superoxide dismutase and arbuscular mycorrhizal fungi: Relationship between the isoenzyme pattern and the colonizing fungus. Symbiosis 24:247-257.

Mathur, N., and A. Vyas. 1995. Changes in isoenzyme patterns of peroxidase and polyphenoloxidase by VAM fungi in roots of Ziziphus species. Journal of Plant Physiology 145:498-500.

Matsumura, A., S. Horii, and T. Ishii. 2007. Effects of arbuscular mycorrhizal fungi and intercropping with bahiagrass on growth and anti-oxidative enzyme activity of radish. Journal of the Japanese Society for Horticultural Science 76:224-229.

Mayer, A.M. 2006. Polyphenol oxidases in plants and fungi: Going places? A review. Phytochemistry 67:2318-2331.

Mittler, R. 2002. Oxidative stress, antioxidants and stress tolerance. Trends in Plant Science 7:405-410.

Morales Vela, G., N. Molinero-Rosales, J.A. Ocampo, and J.M. García-Garrido. 2007. Endocellulase activity is associated with arbuscular mycorrhizal spread in pea symbiotic mutants but not with its ethylene content in root. Soil Biology and Biochemistry 39:786-792.

Palma, J.M., M.A. Longa, L.A. del Río, and J. Arines. 1993. Superoxide-dismutase in vesicular arbuscular-mycorrhizal redclover plants. Physiologia Plantarum 87:77-83.

Passardi, F., C. Penel, and C. Dunand. 2004. Performing the paradoxical: how plant peroxidases modify the cell wall. Trends in Plant Science 9:534-540.

Pérez, E., Y. Rodríguez, M.A. Hernández, y B.M. de la Noval. 2004. Dinámica de inducción de algunos sistemas de defensa en la interacción HMA-tomate (Lycopersicon esculentum Mill.) var. Amalia. II. Inducción y expresión de peroxidasas y polifenoloxidasas en raíces de tomate. Cultivos Tropicales 25(2):45-52

Phillips, J.M., and D.E. Hayman. 1970. Improved procedures for clearing roots and staining parasitic and vesicular-arbuscular mycorrhizal fungi for rapid assessment of infection. Transactions of the British Mycological Society 55:158-161.

Pozo, M.J. 1999. Inducción de enzimas hidrolíticas en raíces de tomate (Lycopersicon esculentum) como respuesta a la formación de MA y su implicación en el control biológico de Phythophtora parasitica. Tesis de doctorado. Universidad de Granada, Facultad de Ciencias, Granada, España.

Pozo, M.J., C. Cordier, E. Dumas-Gaudot, S. Gianinazzi, J.M Barea, and C. Azcon-Aguilar. 2002. Localized versus systemic effect of arbuscular mycorrhizal fungi on defence responses to Phytophtora infection in tomato plants. Journal of Experimental Botany 53:525-534.
Redecker, D., R. Kodner, and L.E. Graham. 2000. Glomalean fungi from the Ordovician. Science 289:1920-1921

Rivera, R., F. Fernández, K. Fernández, L. Ruiz, C. Sánchez, and M Riera. 2007. Advances in the management of effective arbuscular mycorrhizal symbiosis in tropical ecosystems. p. 151-195. In Hamel, Ch., and Ch. Plenchette (eds.) Mycorrhizae in crop production. Haworth Press, Binghampton, New York, USA.

Rodríguez, Y., Y. Dalpé, S. Séguin, K. Fernández, F. Fernández, and R.A. Rivera. 2011. Glomus cubense sp. nov., an arbuscular mycorrhizal fungus from Cuba. Mycotaxon 118:337-347.

Rodríguez, Y., E. Pérez, E. Solórzano, A. Meneses, and F. Fernández. 2001. Peroxidase and polyphenoloxidase activities in tomato roots inoculated with Glomus clarum or Glomus fasciculatum. Cultivos Tropicales 22:11-16

Salzer, P., H. Corbiere, and T. Boller. 1999. Hydrogen peroxide accumulation in Medicago truncatula roots colonized by the arbuscular mycorrhiza-forming fungus Glomus intraradices Planta 208:319-325.

Scervino, J.M., M.A. Ponce, R. Erra-Bassels, J. Bompadre, H Vierheilig, J.A. Ocampo, and A. Godeas. 2007. The effects of flavones and flavonols on colonization of tomato plants by arbuscular mycorrhizal fungi of the genera Gigaspora and Glomus. Canadian Journal of Microbiology 53:702-700.

Scervino, J.M., M.A. Ponce, R. Erra-Bassels, H. Vierheilig, J.A Ocampo, and A. Godeas. 2005. Flavonoids exhibit fungal species and genus specific effects on the presymbiotic growth of Gigaspora and Glomus. Mycological Research 109:789-794.

Scervino, J.M., M.A. Ponce, I.D. Monica, H. Vierheilig, J.A Ocampo, and A. Godeas. 2009. Development of arbuscular mycorrhizal fungi in the presence of different patterns of Trifolium repens shoot flavonoids. Journal of Soil Science and Plant Nutrition 9:102-115.

Smith, S., and D. Read. 2008. Mycorrhizal Symbiosis. $3^{\text {rd }}$ ed. 606 p. Academic Press, London, UK.

Soil Survey Staff. 2006. Keys to soil taxonomy. 10 ${ }^{\text {th }}$ ed. Natural Resource Conservation Service, USDA, Washington, DC., USA.

Spanu, P., and P. Bonfante-Fasolo. 1988. Cell-wall-bound peroxidase activity in roots of mycorrhizal Allium porrum. New Phytologist 109:119-124

Trouvelot, A., J. Kough, et V. Gianinazzi-Pearson. 1986. Mesure du taux de mycorhization VA d'un systeme radiculaire. Recherche de ethods d'estimation ayant une signification fonctionnelle. p. 217-221. In Gianinazzi-Pearson, V., and S. Gianinazzi (eds.) Proceedings of the $1^{\text {st }}$ European Symposium on Mycorrhizae: Physiological and genetical aspects of mycorrhizae. INRA Press, Paris, France.

Vallejos, C.E. 1983. Enzyme activity staining. p. 257-287. In Tanskley, S., and D. Orton (eds.) Isozymes in plant genetic and breeding. Elsevier, Amsterdam, The Netherlands.

Vierheilig, H. 2004. Regulatory mechanisms during the plantarbuscular mycorrhizal fungus interaction. Canadian Journal of Botany 82:1166-1176 